\title{
O FINANCIAMENTO DA EDUCAÇÃO SUPERIOR NO UMIAR DO SÉCULO XXI: O CAMINHO DA MERCANTILIZAÇÃO DA EDUCAÇÃO
}

\author{
HIGHER EDUCATION FUNDING ON THE THRESHOLD OF THE 21ST CENTURY: \\ THE PATHWAY TO MERCANTILIZATION OF EDUCATION
}

\section{EL FINANCIAMIENTO DE LA EDUCACIÓN SUPERIOR EN EL UMBRAL DEL SIGLO XXI: EL CAMINO DE LA COMERCIALIZACIÓN DE LA EDUCACIÓN}

\author{
Altair Alberto Fávero ${ }^{1}$ \\ Diego Bechi ${ }^{2}$
}

\begin{abstract}
RESUMO
O artigo apresenta um panorama do financiamento da educação superior no Brasil no contexto de sua expansão que vem ocorrendo nas últimas duas décadas. Os autores indicam que há uma forte e perceptível tendência à mercantilização da educação decorrente da forma como as políticas educacionais vêm sendo conduzidas pelo governo brasileiro, como parte da lógica neoliberal e pela pressão dos organismos multilaterais. O artigo inicia apresentando (1) as fontes de recursos das instituições públicas e privadas, para em seguida analisar de que forma (2) as estimativas do investimento público indicam sinais da mercantilização da educação superior. $\mathrm{O}$ artigo é resultado parcial do projeto de pesquisa vinculado à Rede de Estudos e Pesquisas sobre Educação Superior (REPES), cadastrado junto ao CNPq.
\end{abstract}

PALAVRAS-CHAVE: Educação Superior. Financiamento. Mmercantilização da educação.

\begin{abstract}
The present article presents an overview of the funding of higher education in Brazil within a context of its expansion which has occurred in the last decades. These authors indicate that there is a strong and perceptible trend to mercantilization of education, resulting from the way in which educational policies have been managed by the Brazilian government, as part of the neoliberal rationale and by the pressure of multilateral bodies. This article begins by introducing (1) the sources of public and private institutions' resources in order to afterwards analyze how (2) the estimates of public funds indicate signs of mercantilization in higher education. This paper is a partial result of a research project which is linked to the Network of Studies and Research Projects on Higher Education (REPES), registered at CNPq.
\end{abstract}

KEYWORDS: Higher education. Funding. Mercantilization of education.

\section{RESUMEN}

El artículo presenta un panorama de la financiación de educación superior en Brasil en el contexto de su expansión que ha tenido lugar en las últimas dos décadas. Los autores indican que hay una tendencia fuerte y evidente hacia la mercantilización de la educación debido a la forma en que las políticas educativas se llevan a cabo por el gobierno brasileño como parte de la lógica neoliberal y la presión de las organizaciones multilaterales. El artículo comienza presentando (1) las fuentes de financiación de las instituciones públicas y privadas, a continuación, analizar la forma (2) las estimaciones de inversión pública muestran signos de mercantilización de la educación superior. El artículo es el resultado parcial del proyecto de investigación relacionado con la Red de Estudios e Investigación sobre la Educación Superior (Repes), inscrita en el CNPq.

PALABRAS CLAVE: Educación universitária. Financiación. Mercantilización de la educación.

\footnotetext{
${ }^{1}$ Universidade de Passo Fundo - Passo Fundo, RS. - E-mail: altairfavero@ gmail.com - ORCID: http://orcid.org/0000-0002-9187-7283

${ }^{2}$ Universidade de Passo Fundo - Passo Fundo, RS. - E-mail: diego_bechi@yahoo.com.br

Submetido em:04/12/2016 - Aceito em: 17/01/2017 - Publicado em: 14/02/2017.
}

\begin{tabular}{l|l|l|l|l|l|l} 
(C) Rev. Inter. Educ. Sup. & Campinas, SP & v.3 & n.1 & p.90-113 & jan./abr. 2017 & ISSN 2446-9424 \\
\hline
\end{tabular}




\section{INTRODUÇÃO}

[...] simultaneamente livre dos recursos orçamentários necessários para sua manutenção e desenvolvimento, e livre para vender ensinomercadoria (diplomas) e conhecimento-mercadoria (patentes), a universidade (publica?) estará pronta para disputar no mercado, inclusive concorrendo com as universidades privadas, os recursos necessários para permanecer existindo. (RODRIGUES, 2007, p.82).

Tratar do financiamento da educação superior no Brasil, no atual cenário das políticas educacionais, implica em analisar um conjunto de fatores socioeconômicos, bem como compreender a atuação de diversos atores institucionais. Isso significa dizer que a problemática da educação superior brasileira não pode ser abordada sem ter presente a construção do Estado neoliberal, a influência do processo de globalização econômica, a crise o Estado de bem-estar social e a emergência do neoliberalismo, a escassez de recursos do Estado e a adoção de estratégias de mercantilização da educação.

Diversos autores (OLIVEIRA, 2009; SANFELICE, 2003; GOERGEN, 2005; FRIGOTTO, 2006; IANNI, 1995) são unânimes em afirmar que a problemática da educação superior brasileira se articula "a consolidação do projeto societário capitalista neoliberal" (SEVERINO, 2008, p.76), o qual reserva para o Brasil a condição de ter um lugar secundário na divisão social do trabalho. Nesse projeto, a educação cumpre o papel de "preparação de mão de obra para o mercado de trabalho" e se torna subserviente ao modelo econômico que impõe sua lógica de funcionamento. Nessa lógica, os interesses do capital se sobrepõem a todos os outros interesses. Como bem ressalta em seus estudos Nicholas Davies (2010, p.231), "o governo federal [brasileiro] gasta muito mais com juros e amortização da dívida publica (em outras palavras, com os bancos) do que com programas 'sociais', como a bolsa família”. O Brasil tem assistindo a implantação dessa lógica quando viu reduzir os gastos na área dita social (saúde, educação, saneamento básico etc.), privatizar setores estatais mercantilizáveis e, ao mesmo tempo, "ampliar os gastos públicos para o pagamento de juros e a amortização da dívida estatal [...]” (Idem).

A imersão dessa lógica do modelo econômico se faz sentir na forma como o poder público brasileiro, desde meados dos anos de 1990, busca implementar, com base na legislação e por meio de diversos programas, "uma política de diversificação e diferenciação" (SEVERINO, 2008, p.84), com a finalidade de ajustar o sistema de educação superior, adotando princípios de flexibilidade, competitividade e avaliação (OLIVEIRA, 2006, p.11) claramente sintonizados com as pressões da agenda neoliberal que vem se impondo de forma soberana de forma contundente. Conforme ressalta Severino $(2008$, p.84) "esse processo vai ao encontro à forte tendência de mercantilização dos serviços educacionais e à consequente privatização do ensino superior, sempre com a alegação da necessidade de atender melhor às demandas sociais, bem como aquelas do mercado de trabalho".

O financiamento da pesquisa e da pós-graduação nas Instituições Federais de Ensino Superior (IFES) apresenta sinais inconfundíveis de que está ocorrendo um processo de mercantilização da educação. Frente à escassez de recursos governamentais voltados para a

n. 1
p.90-113 jan./abr. 2017 ISSN 2446-9424 
manutenção e o investimento das universidades públicas federais (infraestrutura adequada para desenvolver as pesquisas, laboratórios de tecnologia de ponta, expansão pesquisa e da pós-graduação), "as administrações das IFES vêm sendo induzidas a buscar novas formas de captação de recursos, de forma a complementar o aporte de recursos federais e viabilizar o funcionamento de suas atividades" (FARIA; FRANCISCO; MELLO, 2006, p.1). Essas "novas formas de captação de recursos" são consideradas estratégias de sobrevivência frente à situação financeira problemática que se encontram tais instituições. Para Boaventura de Sousa Santos (2004), o fato de a universidade pública ser induzida a ultrapassar a crise financeira mediante a geração de receitas próprias, consiste no primeiro nível de mercantilização.

O presente artigo tem por objetivo analisar de que forma os fatores socioeconômicos, a legislação e os diversos atores institucionais interferiram no delineamento do financiamento da educação superior para o caminho da mercantilização. Na primeira parte (1) apresenta-se as fontes de recursos das instituições públicas e privadas, para em seguida analisar de que forma (2) as estimativas do investimento público indicam sinais da mercantilização da educação superior.

\section{AS FONTES DE RECURSOS DAS INSTITUIÇões PÚBLICAS E PRIVADAS}

A Unesco, em sua Conferência Mundial sobre o Ensino Superior (Paris/1998), elaborou o documento "Declaração mundial sobre educação superior no século XXI: visão e ação", em que faz uma análise das funções e dos compromissos da educação superior para o novo século. Em seu artigo 14, intitulado "O financiamento da educação superior como serviço público", expressa-se o papel da sociedade em seu conjunto - incluindo, os setores públicos e privados da economia, meios de comunicação, estudantes, organizações governamentais e não governamentais - no fortalecimento do setor educacional em âmbito internacional. Para tanto, parte-se do pressuposto de que o financiamento da educação superior requer recursos públicos e privados, mas cabe ao Estado assegurar a manutenção, o desenvolvimento e a qualidade do ensino e da pesquisa em rede nacional. É nesse espírito que a Unesco (art. 14), embora ciente da necessidade de diversificação das fontes de financiamento, enfatiza o caráter público da educação superior:

O Estado mantém seu papel essencial nesse financiamento. O financiamento público da educação superior reflete o apoio que a sociedade presta a esta educação e deve, portanto, continuar sendo reforçado, a fim de garantir o desenvolvimento da educação superior, aumentar a eficácia e manter sua qualidade e relevância. Não obstante, o apoio público à educação superior e à pesquisa permanece essencial, sobretudo como forma de assegurar um equilíbrio na realização de missões educativas e sociais.

No Brasil, o funcionamento e o desenvolvimento das instituições públicas de ensino superior dependem quase exclusivamente dos recursos financeiros provenientes do setor público, em função do custo elevado das atividades envolvendo o ensino a pesquisa e a 
extensão. Em observância a Constituição Federal (CF/88) e a legislação educacional vigente, em especial a Lei de Diretrizes e Bases da Educação Nacional (LDBN/96), o Estado é responsável pela oferta de educação superior, gratuita e de qualidade, em universidades e institutos especializados, de forma a garantir a utilização de laboratórios sofisticados e o provimento de recursos materiais e financeiros necessários ao desenvolvimento das atividades de pesquisa e de extensão. Nos termos constitucionais, cabe ao Estado assegurar a todos os cidadãos o direito à educação (art. 205), alicerçando-se nos princípios da gratuidade, da igualdade de condições para o acesso e permanência, da gestão democrática e da garantia de padrão de qualidade do ensino público em estabelecimentos oficiais (art. 206). Concomitantemente, parte-se do princípio de que as universidades e as instituições de pesquisa científica e tecnológica gozam de autonomia didático-científica, administrativa e de gestão financeira e patrimonial (art. 207). Nessa direção, o artigo 55 da Lei de Diretrizes e Bases da Educação (LDB/96) é enfático ao estabelecer que "caberá à União assegurar, anualmente, em seu Orçamento Geral, recursos suficientes para a manutenção e desenvolvimento das instituições de educação por ela mantidas".

$\mathrm{Na}$ primeira década do século XXI, as receitas oriundas do Tesouro Nacional $^{3}$ corresponderam a aproximadamente $88 \%$ do total de recursos obtidos pelas universidades federais brasileiras ${ }^{4}$. Essa modalidade de financiamento, por vezes denominada de incremental ou inercial, "envolve práticas de destinação de verbas segundo o orçamento do ano anterior de cada instituição, o que, em geral, é negociado entre instituições e governo, sendo as decisões baseadas em modelos ad hoc que variam segundo os cenários econômico e político" (CORBUCCI; MARQUES, 2003, p. 13). O restante dos recursos tem sido obtido via convênios, taxas cobradas e serviços eventuais prestados pelas instituições. Assim, cada instituição procurou estabelecer o maior número possível de convênios ou contratos de gestão, pois é uma forma permitida pela legislação para complementar suas receitas e driblar as restrições orçamentárias. Os convênios/contratos com organismos públicos e/ou privados, celebrados em âmbito federal, estadual e municipal, constituíram-se na segunda maior fonte de recursos em todas as universidades federais, representando em média $8 \%$ da receita total.

A operacionalização de contratos de gestão tem viabilizado a captação de recursos financeiros mediante o estabelecimento de parcerias entre as instituições públicas e as empresas privadas, conforme preconiza a lei no 10. 973 (Lei de Inovação Tecnológica), de 02 de dezembro de 2004, que dispõe sobre incentivos à inovação e à pesquisa científica e tecnológica no ambiente produtivo. As medidas adotadas pelo governo federal para subsidiar o desenvolvimento científico e tecnológico no interior das universidades públicas mantêm

\footnotetext{
3 Quanto às fontes de financiamento da educação superior brasileira, é importante salientar que, do total de recursos despendidos pelo Tesouro Nacional, as universidades públicas recebem apenas a parte que é destinada ao custeio e capital. Em função da falta de autonomia das IFES para gerir suas despesas, o pagamento de funcionários e pensionistas, equivalente a maior parcela de recursos, é remetido diretamente aos beneficiários pelo Governo Central (COSTA QUINTANA, SAURIN, 2005, p. 08).

As estimativas das receitas por fontes de recursos e das despesas das instituições federais de educação superior foram consubstanciadas com base nos estudos de Amaral (2009, 2008b), Soares et. al (2009) e Freitas et. al (2005).
}

(C) Rev. Inter. Educ. Sup.

\begin{tabular}{l|l|l} 
Campinas, SP & v.3
\end{tabular}

n.1

p. $90-113$

jan./abr. 2017

ISSN 2446-9424 
ativas as projeções do Banco Mundial para a educação superior, sumarizadas no documento intitulado La Ensenãnza Superior: las perspectivas de La experiência (1995). As diretrizes para as reformas da educação superior apregoadas aos países em desenvolvimento, inclusive ao Brasil, consubstanciadas em favor do processo de modernização do Estado, preconizado e disseminado pelos organismos financeiros internacionais (Banco Mundial, FMI e BID), tencionaram os governos a reduzir os gastos públicos em educação e, em contrapartida, estimularam a diversificação das fontes de financiamento das universidades públicas. (AMARAL, 2003)

A segunda referência concreta e atual desta operacionalização é o Programa de Apoio a Planos de Reestruturação e Expansão das Universidades Federais (Reuni). O Programa, instituído pelo decreto $\mathrm{n}^{0}$ 6.096, de 24 de abril de 2007, tem por objetivo dotar as universidades federais das condições necessárias para a ampliação do acesso e a permanência de jovens na educação superior. As universidades que aderiram ao plano de reestruturação deveriam indicar estratégias e etapas para a realização dos objetivos propostos pelo Programa. Caberia a cada instituição de ensino elevar as taxas de conclusão dos cursos de graduação para $90 \%$ e a relação de estudantes de graduação em cursos presenciais por professor para dezoito. Além disso, o programa prevê a ampliação da mobilidade estudantil entre as instituições de ensino, o aumento de vagas no período noturno, a reorganização dos cursos de graduação e a diversificação das modalidades de educação, preferencialmente não voltadas à profissionalização precoce e especializada. Para efeitos do contrato de gestão, as referidas metas deverão ser cumpridas no prazo de cinco anos, a contar do início de cada plano (BRASIL, 2007b).

Em contrapartida, o Ministério da Educação propôs um limitado acréscimo de vinte por cento das despesas de custeio e pessoal para cada universidade federal que aderir ao plano de reestruturação. Mas, nos termos do decreto de criação do Reuni, os recursos adicionais necessários ao cumprimento das metas fixadas pela instituição, em atendimento aos objetivos do programa, "correrão à conta das dotações orçamentárias anualmente consignadas ao Ministério da Educação" (BRASIL, 2007b). Todavia, a partir de 2008, com a implementação do "termo de pactuação de metas", o volume de recursos financeiros destinados à expansão do setor público federal cresceu significativamente. As medidas políticas adotadas pelo governo federal a fim de ampliar o acesso e a permanência na educação superior mantiveram-se entre as ações de maior impacto financeiro e social anexadas ao Plano de Desenvolvimento da Educação (PDE), conhecido como PAC da educação ${ }^{5}$. De acordo com Chaves (2011, p. 07), no período de 2007 a 2008, os recursos

\footnotetext{
${ }^{5}$ Ao analisar o Plano de Desenvolvimento da Educação (PDE) no que concerne ao seu financiamento e ações, deparamo-nos com alguns problemas estruturais relativos à falta de dados sistematizados, pois não existe no sítio oficial do Ministério da Educação nenhum quadro que sintetize os programas e as ações relativas aos diferentes níveis e modalidades de ensino. A proposta do PAC da educação está diluída em uma longa série de Decretos, Portarias, Termos, Chamadas, Resoluções, Projetos de Lei, entre outros atos normativos. Em virtude da fragmentação de suas ações e da ausência de um diagnóstico da educação nacional, o PDE não possui as características de um plano, em sentido próprio. Segundo Saviani (2007, p. 1239), "ele se define, antes, como um conjunto de ações que, teoricamente, se constituiriam em estratégia para a realização dos objetivos e metas \begin{tabular}{l|l|l|l|l|l|l} 
(C) Rev. Inter. Educ. Sup. & Campinas, SP & v.3 & n.1 & p.90-113 & jan./abr. 2017 & ISSN 2446-9424 \\
\hline
\end{tabular}
} 
investidos na expansão do acesso e permanência de jovens nas IFES aumentaram "aproximadamente 179\%. Em 2009, as despesas com o Reuni representaram 69,4 \% no conjunto das despesas com expansão".

A terceira fonte relevante de financiamento provém de receitas próprias. Esses recursos suplementares são captados de diferentes formas, dentre as quais a prestação de serviços pelas diversas unidades da instituição, incluindo a oferta de cursos de especialização latu sensu (autofinanciáveis) e extensão, assessorias e consultorias; a prestação de serviços ao Sistema Único de Saúde (SUS) pelos hospitais universitários (HUs); as aplicações no mercado financeiro e a cobrança de taxas, aluguéis e arrendamentos. Essas receitas representaram, na primeira década do século XXI, em média 4\% do total das fontes de recursos das universidades federais (SOARES et. al., 2009; FREITAS et.al., 2005; AMARAL, 2008b). Assim, as fontes de recursos próprios, adicionadas às receitas governamentais e às fontes de recursos oriundas do setor privado, vinculadas aos convênios e contratos firmados com órgãos públicos e com o setor empresarial, acrescem a receita orçamentária das instituições federais de educação superior. A captação e a vinculação de recursos públicos e privados ao orçamento das universidades federais amenizam os problemas de ordem estrutural, de manutenção e de investimentos decorrentes das limitações do Estado no provimento de recursos financeiros para o setor. Isso porque, as receitas oriundas do Tesouro Nacional cobrem quase exclusivamente as despesas obrigatórias, referentes aos dispêndios de pessoal e encargos sociais, e aproximadamente $80 \%$ das despesas de custeio e de capital, induzindo-as a buscar fontes alternativas de financiamento, de forma a complementar o aporte de recursos federais. (VASCONCELOS; BARBOSA, 2009).

Em função da complexa estrutura e das exigências relativas ao desenvolvimento do ensino, da pesquisa e da extensão, as universidades federais brasileiras compreendem despesas de grande impacto financeiro. A despesa mais relevante na totalidade das instituições, registradas na primeira década do século XXI, estão associadas ao pagamento de pessoal e encargos sociais, comprometendo cerca de $80 \%$ da receita total das instituições. As despesas dessa natureza são de caráter remuneratório, incluindo: o efetivo exercício de cargo, emprego ou função de confiança no setor público; os proventos de aposentadorias, reformas e pensões; as obrigações trabalhistas de responsabilidade do empregador; os incidentes sobre a folha de salários; as contribuições a entidades fechadas de previdência; as despesas com a contratação temporária para atender a necessidade de interesse público e despesas com contratos de terceirização de mão-de-obra. (STN/SOF, 2001). A segunda maior despesa esteve vinculada às despesas de custeio e manutenção das universidades, montante que absorveu em média $18 \%$ dos recursos orçamentários de cada instituição. O capital/investimento aparece em terceiro lugar com uma média de $2 \%$ do total. De acordo com a Portaria Interministerial $n^{\circ} 163 / 2001$, as despesas de investimento são as que envolvem "o planejamento e a execução de obras, inclusive com a aquisição de imóveis considerados

previstos no PNE". Para obter maiores esclarecimentos sobre a origem, a estrutura e o financiamento das ações do PDE, ver Silva e Alves (2009), Camargo et al. (2008) e Saviani (2007).

\begin{tabular}{l|l|l|l|l|l|l} 
(C) Rev. Inter. Educ. Sup. & Campinas, SP & v.3 & n.1 & p.90-113 & jan./abr. 2017 & ISSN 2446-9424 \\
\hline
\end{tabular}


necessários à realização destas últimas, e com a aquisição de instalações, equipamentos e material permanente" (STN/SOF, 2001, p. 13).

No entanto, para dar continuidade a essa análise é preciso levar em conta que a questão do planejamento e orçamento das IES deve ser analisada tomando-se por base a diferenciação quanto à natureza jurídica das instituições (IES públicas ou IES privadas), em virtude de apresentarem estrutura orçamentária diferenciada. Ao contrário das universidades federais, a principal fonte de financiamento das instituições privadas está associada à cobrança de mensalidades aos estudantes matriculados. Mas, em função da elevação dos índices de evasão, inadimplência e ociosidade de vagas registrados na última década, o setor privado vem sofrendo fortes restrições financeiras e orçamentárias. Para manter suas atividades e a lucratividade frente ao competitivo mercado educacional, as IES privadas passaram a buscar fontes alternativas de financiamento junto ao campo empresarial, ao mercado de capitais (bolsa de valores) e ao governo federal. Na interpretação de Costa Quintana e Saurin (2005, p. 3), essas instituições estão habilitadas a utilizar o orçamento empresarial, ou seja, "a partir de um planejamento estratégico, elaborar um orçamento global no qual seriam projetados os orçamentos: operacional, financeiro e de investimentos, bastando, para isto, que o administrador da instituição promova um processo de estruturação deste orçamento".

A receita das instituições privadas de ensino superior tem sido complementada com o apoio de várias fontes diretas (subsídios, bolsas, empréstimos, crédito educativo, dentre outras) e, sobretudo, indiretas (isenções tributárias e previdenciárias) de recursos públicos. A aplicação de recursos governamentais no setor privado aumentou a disponibilidade financeira e reduziu, indiretamente, as despesas de ordem fiscal das instituições, contribuindo significativamente para a sua manutenção e expansão. Segundo Davies (2002, p. 04), "sem tais fontes diretas e indiretas, as instituições privadas perderiam uma fatia substancial de seu mercado, pois as mensalidades teriam que ser bem maiores para cobrir os custos e/ou manter a alta taxa de lucratividade do setor". Com efeito, vê-se a oferta de duas distintas fontes públicas para o financiamento das instituições privadas: o ProUni e o Fies. Esses dois programas governamentais, subsidiados pelo Ministério da Educação, foram criados com o objetivo de ampliar o acesso ao ensino superior a grupos de maior vulnerabilidade educacional, mediante a concessão de bolsas de estudos e a oferta de financiamento estudantil.

O Programa Universidade para Todos (ProUni), lançado oficialmente em 13 de maio de 2004, criado pela Medida Provisória ${ }^{\circ}$ 13, de 10 de outubro de 2004, e instituído pela lei $\mathrm{n}^{\circ} 11.096 / 2005$, tornou-se a principal fonte de financiamento público (indireto) direcionado ao setor privado para a delegação de políticas sociais. Essa iniciativa política, formalizada pelo Ministério da Educação, contemplou dois interesses básicos: a) o social, mediante a concessão de bolsas de estudos integrais e parciais (25\% a 50\%) em cursos de graduação e sequenciais específicos, a estudantes brasileiros de baixa renda não portadores de diploma de nível superior e àqueles em situação que requer a adoção de políticas afirmativas; e b) o

\begin{tabular}{l|l|l|l|l|l|l|} 
(C) Rev. Inter. Educ. Sup. & Campinas, SP & v.3 & n.1 & p.90-113 & jan./abr. 2017 & ISSN 2446-9424
\end{tabular}


econômico, ao garantir a isenção fiscal às instituições privadas (com ou sem fins lucrativos) vinculadas ao programa. Na prática, os estabelecimentos credenciados ao ProUni disponibilizam a sua estrutura física e os cursos de formação para a sociedade em troca de imunidade e isenção de tributos ${ }^{6}$.

A parceria entre o público e o privado na promoção de políticas sociais, financiada por meio da renúncia fiscal, aumentou a disponibilidade econômica dos estabelecimentos educacionais e, por conseguinte, diminuiu a arrecadação potencial do Estado. A política econômica articulada ao ProUni impulsionou o desenvolvimento das instituições de ensino superior privadas na medida em que lhes atribuiu novas funções sociais e fortaleceu-as financeiramente. A desoneração fiscal de caráter social evitou possíveis falências e fechamentos de cursos previstos nas reivindicações realizadas pelas associações representantes das instituições privadas. O financiamento público destinado ao segmento privado tem sido a principal solução encontrada pelo Poder Público para diminuir as dificuldades financeiras decorrentes das altas taxas de inadimplência e ociosidade de vagas ocasionada pela evasão, aumento vertiginoso do número de instituições privadas e desistência do alunado (CARVALHO, 2011). Em termos de materialidade, de 2006 a 2009 o governo renunciou a mais de $\mathrm{R} \$ 1$ bilhão para a consecução dos objetivos atribuídos ao programa. De acordo com os demonstrativos dos gastos tributários da Secretária da Receita Federal (SRF) do Ministério da Fazenda, a estimativa para a renúncia de receitas via ProUni para o ano de 2010, em valores correntes, era de $\mathrm{R} \$ 625$. 367.277, diminuiu para $\mathrm{R} \$$ 510.901.338, em 2011, atingindo R\$733.904.013, em 2012. Entre 2013 e 2014 houve uma queda nos gastos indiretos de $\mathrm{R} \$ 149.825 .010$ (19\%). No ano de 2015 registrou-se um aumento na perspectiva de investimento de $61 \%(\mathrm{R} \$ 369.316 .137$ ) comparado ao ano anterior, chegando a $\mathrm{R} \$$ 1.279.543.726 em 2016. Em 2017, o governo federal pretende investir indiretamente R\$ 1.326.928.094 na compra de vagas em IES privadas (SRF, 2007-2017).

\footnotetext{
${ }^{6}$ A arrecadação compulsória de recursos, que em termos técnicos caracteriza a tributação de um país, é utilizada pelos governos para financiar os gastos públicos. O sistema tributário legal é composto por um conjunto de normas que definem e delimitam o processo de arrecadação de impostos. Embora não possua outro objetivo que não gerar recursos para a administração, o sistema tributário é permeado de desonerações (isenções, anistias, reduções de alíquota, presunções creditícias, entre outras). Em sentido amplo, elas podem servir para diversos fins. Por exemplo: "a) simplificar e/ou diminuir os custos da administração; b) promover a equidade; c) corrigir desvios; d) compensar gastos realizados pelos contribuintes com serviços não atendidos pelos governos; e) compensar ações complementares às funções típicas do Estado desenvolvidas por entidades civis; $\mathrm{f}$ ) promover a equalização das rendas entre regiões; e/ou d) incentivar determinado setor da economia" (SRF, 2012, p. 06-07).

\begin{tabular}{l|c|c|c|c|c|c|} 
(C) Rev. Inter. Educ. Sup. & Campinas, SP & v.3 & n.1 & p.90-113 & jan./abr. 2017 & ISSN 2446-9424 \\
\hline
\end{tabular}
}




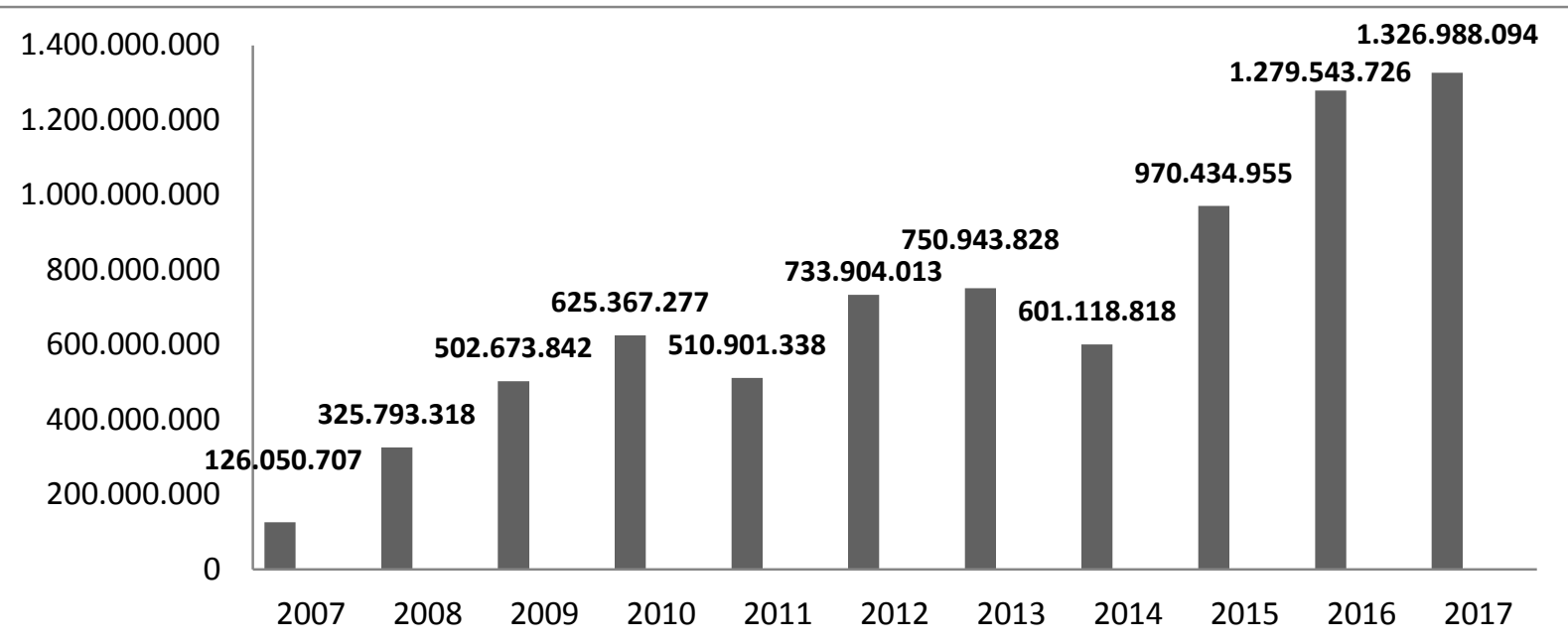

Gráfico 1. Previsão dos Gastos Tributários referentes ao Prouni - 2007 a 2017 Fonte: SRF/DGT. Elaboração própria.

Com base nessas informações, é importante destacar que as desonerações tributárias destinadas à iniciativa privada possuem objetivos similares aos das despesas públicas. No Brasil, o conceito de "benefício tributário" adotado pela Secretaria da Receita Federal (SRF) para designar as despesas relativas às desonerações, foi substituído, a partir de 2004, pela expressão "gasto tributário". Em tese, a nova terminologia, aprovada com o propósito de promover uma maior uniformização com o entendimento utilizado em outros países, abarcou o seguinte conceito: "gastos tributários são gastos indiretos do governo realizados por intermédio do sistema tributário visando atender objetivos econômicos e sociais" (SRF, 2012, p. 11). A ampliação dos gastos públicos para a consecução de políticas sociais, efetuados por intermédio do sistema tributário, abrange a história recente da educação superior brasileira. Todavia, o financiamento indireto concedido pelo Estado via ProUni tem recebido um considerável número de críticas, que focalizam, dentre outros pontos, a concessão de bolsas integrais e parciais na rede privada. Lima (2011) considera esse tipo de parceria na educação como uma extensão das políticas do governo Cardoso. A criação do ProUni, no decorrer do primeiro mandato presidencial de Lula da Silva, teria consolidado as políticas de cunho neoliberal defendidas pelos organismos internacionais de financiamento, a exemplo do Banco Mundial, que sugere a ampliação das oportunidades educacionais a um custo mais baixo para o fundo público, mediante a expansão das instituições privadas e a criação de cursos breves ou dedicados exclusivamente ao ensino.

A segunda fonte de recursos públicos direcionada ao financiamento das instituições de ensino superior privadas no Brasil, especificamente na primeira década do século XXI, consubstanciou-se a partir do programa de Financiamento Estudantil (FIES), instituído pelo Ministério da Educação com a pretensão de financiar os estudantes de graduação matriculados em IES não gratuitas. A implementação da lei $\mathrm{n}^{\circ} 10.260$, de 12 de junho de 2001, que dispõe sobre o Fundo de Financiamento ao Estudante do Ensino Superior, proporcionou incentivos públicos diretos (títulos da dívida pública) e indiretos (isenção previdenciária) ao setor privado. De maneira geral, as IES participantes do Fies "recebem

\begin{tabular}{l|l|l|l|l|l|l} 
(c) Rev. Inter. Educ. Sup. & Campinas, SP & v.3 & n.1 & p.90-113 & jan./abr. 2017 & ISSN 2446-9424 \\
\hline
\end{tabular}


como contrapartida títulos da dívida pública, do tipo CTF-E, no valor da parcela das semestralidades não financiadas pelos estudantes, que podem ser utilizados para quitar débitos previdenciários junto ao INSS, negociados no mercado secundário, ou renegociados com o Fundo" (TCU, 2009, p. 69). Além dos recursos concedidos de maneira indireta pelo Estado (isenções fiscais/ProUni e previdenciárias/Fies), há a possibilidade de as IES renegociarem com o Fundo os títulos recebidos da Caixa Econômica Federal. Essa renegociação rende às instituições um montante de recursos públicos equivalente ao valor financiado pelos alunos do Fies. Para se ter uma ideia, no período de 2004 a 2007 foram repassados às instituições participantes aproximadamente $\mathrm{R} \$ 2,6$ bilhões, em títulos da dívida pública. Entre 2004 e 2014, os gastos com o funcionamento e o investimento em Instituições federais e Ensino Superior (IFES) saltaram de $\mathrm{R} \$ 2,5$ bilhões para $\mathrm{R} \$$ 8,7 bilhões, representando um aumento de $245 \%$ em valores correntes. Concomitantemente, o gasto do governo com o Fies cresceu 1,1 mil \%, atingindo R \$ 13,7 bilhões, em 2014, para uma base de $\mathrm{R} \$ 1,1$ bilhões, em 2004, ultrapassando em $56 \%$ o total de recursos despendidos às IFES.

Em suma, o processo de financiamento da educação superior no limiar do século XXI tem se pautado na racionalização e otimização dos recursos públicos, na parceria públicoprivada (PPP) e na abertura ao mercado/campo empresarial, de modo a aproximar a universidade do modelo de empresas prestadoras de serviço. As políticas educacionais de caráter neoliberal, visivelmente articuladas à lógica econômica do custo-benefício, propiciaram alterações substantivas na agenda da educação superior, acarretando sérios prejuízos à pesquisa cientifica e ao desenvolvimento tecnológico do país (BECHI, 2013). Em observância à problemática, cabe agora investigar o quantum foi gasto com o ensino superior (graduação, mestrado e doutorado), a fim de esclarecer os avanços e os limites do financiamento público no período de 2001 a 2011. Nesse sentido, apresentam-se diferentes estimativas do investimento público (direto e indireto) nesse nível de ensino, incluindo: o percentual de investimento em relação ao Produto Interno Bruto (PIB); o histórico dos gastos públicos diretos por estudante na educação superior em valores reais e nominais; a estimativa do investimento público direto por estudante em valores reais, por nível de ensino (educação básica e educação superior); e a proporção relativa do investimento público direto em educação, por nível de ensino (educação básica e educação superior).

\section{ESTIMATIVAS DO INVESTIMENTO PÚBLICO E OS SINAIS DA MERCANTILIZAÇÃ̃O}

A vitória de Luiz Inácio Lula da Silva nas eleições presidenciais de 2002 gerou expectativas de mudanças na política econômica e social do país. O Plano de governo, elaborado com o intuitivo de subsidiar a primeira eleição presidencial do novo século, propusera estabelecer profundas alterações no campo da educação superior brasileira. As diretrizes e metas do Plano comprometiam-se com as ações amplamente defendidas pelos setores da sociedade envolvidos na luta pela melhoria da qualidade da educação no país. O diagnóstico apresentado sinalizava para a necessária ampliação e fortalecimento do setor

(C) Rev. Inter. Educ Sup.

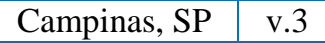

n.1

p.90-113

jan./abr. 2017

ISSN 2446-9424 
público, por meio de políticas de efetivo financiamento estatal (DOURADO, 2009). Para tanto, esperava-se que, ao assumir o ponto máximo da atividade política, a primeira medida a ser tomada pelo governo Lula da Silva seria a derrubada dos vetos presidenciais ao PNE 2001-2010. Mas, embora o programa de governo 2003/2006 tenha se mostrado favorável às expectativas da sociedade civil, os nove vetos impostos por FHC foram mantidos durante os dez anos de vigência do Plano. No início do segundo mandato presidencial, o documento denominado "PDE - razões, princípios e programas", elaborado pelo Ministério da Educação, voltou a refletir sobre a necessidade de se ampliar os recursos para a educação. Diz o documento (2007a, p. 39- 40):

\begin{abstract}
Estudiosos da educação, em especial economistas, tem defendido a tese de que o Brasil não precisa ampliar os investimentos em educação como proporção do Produto Interno Bruto. Alegam que o patamar atual, de 4\%, aproxima-se da média dos países desenvolvidos, o mesmo valendo para a relação entre o investimento na educação básica e o investimento na educação superior, de cerca de quatro para um. Esta abordagem, contudo, perde de vista dois aspectos: nosso baixo PIB per capita e nossa elevada dívida social. Se quisermos acelerar e superar um século de atraso no prazo de uma geração, não há como fazê-lo sem investimentos da educação na ordem de $6 \%$ a $7 \%$ do PIB [...].
\end{abstract}

O aumento dos recursos para a educação, mediante a elevação do percentual do PIB, viabilizaria a ampliação do acesso e a melhoria da qualidade do ensino superior. Porém, na prática, o governo federal não conseguiu atingir a meta que previa o aumento do percentual de gastos públicos, aplicados em educação, previstos no PNE 2001-2010 (Item 11.3, subitem 1). Conforme se observa no gráfico 1, de 2001 até 2010 o percentual do investimento público total em relação ao PIB (todos os níveis) elevou-se de 4,8\% para 5,8\%. Nesse período, não houve avanço em relação ao percentual de investimento com a educação superior, permanecendo na margem dos $0,9 \%$. No último ano do governo FHC (2002), registrou-se uma pequena elevação de $0,1 \%$, atingindo um investimento na ordem de $1 \%$ do PIB na educação superior. Mas, reduziu para 0,8\%, em 2004, permanecendo em baixa até o ano de 2007, início do segundo mandato do governo de Lula da Silva. Em 2014, o percentual total de investimento público atingiu 1,2\% - o maior percentual nesse início de novo século.

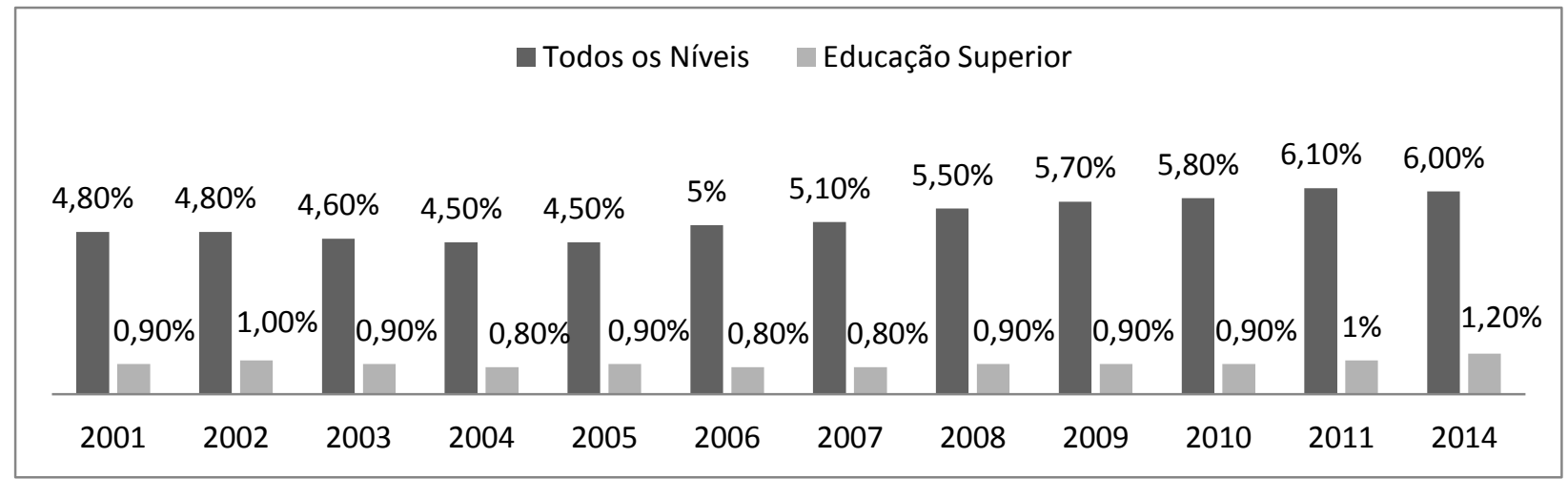

Gráfico 2. Estimativa do percentual do investimento público total na educação superior em relação ao produto interno bruto (PIB) - 2001 a 2011

Fonte: INEP/MEC. Elaboração própria.

\begin{tabular}{l|l|l|l|l|l|l|} 
(C) Rev. Inter. Educ. Sup. & Campinas, SP & v.3 & n.1 & p.90-113 & jan./abr. 2017 & ISSN 2446-9424 \\
\hline
\end{tabular}


Notas: I) Utilizaram-se os seguintes grupos de natureza de despesa: pessoal ativo e encargos sociais (inclusive, a estimativa para complemento da aposentadoria futura do pessoal ativo), outras despesas correntes, investimentos e inversões financeiras; II) Estão computados nos cálculos os recursos para bolsas de estudo, financiamento estudantil, e a modalidade de aplicação: transferências correntes e de capital do setor privado; III) Não se incluem nestas informações as seguintes despesas: aposentadorias e reformas, pensões, juros e encargos da dívida, e amortizações da dívida da área educacional. IV) A educação superior corresponde aos cursos superiores em tecnologia, demais cursos de graduação (exceto os cursos sequenciais) e cursos de pós-graduação Stricto Sensu - mestrado, mestrado profissional, doutorado (excetuando-se as especializações Lato Sensu). V Estes dados referem-se aos investimentos em educação consolidados do Governo Federal, Estado, Distrito Federal e Municípios.

Embora não se tenha atingido o percentual mínimo de $7 \%$ proposto pelo Plano Nacional de Educação, o Estado brasileiro garantiu uma memorável ampliação dos recursos públicos para investimentos no ensino superior em razão dos altos índices de crescimento do Produto Interno Bruto (PIB). No período de 2001 a 2010, esse indicador registrou uma elevação de $\mathrm{R}$ \$ 1,1 trilhão para $\mathrm{R}$ \$ 3,6 trilhões (valores correntes/IBGE), um índice de crescimento de aproximadamente $210 \%$. Ao multiplicar a evolução do PIB pelos percentuais do investimento público em educação superior, registrados no Gráfico 2, tem-se uma elevação dos recursos financeiros de $\mathrm{R} \$ 9,4$ bilhões $(0,9 \%)$, em 2001, para $\mathrm{R} \$ 33$ bilhões $(0,9 \%)$, no último ano do governo Lula da Silva, o que representa uma elevação percentual próxima dos 250\% (valores correntes). Em 2011, o Produto Interno Bruto (PIB) em valores correntes alcançou $\mathrm{R} \$ 4,1$ trilhões. Com isso, o investimento público na educação superior totalizou R $\$ 41,4$ bilhões (1\%), um aumento de aproximadamente $25 \%$ em relação ao ano de 2010. Em 2014, a riqueza gerada pela economia brasileira atingiu $\mathrm{R} \$ 5,52$ trilhões. Ao multiplicá-la pelo percentual de investimento público (Gráfico 2) tem-se um total de aproximadamente 66 bilhões (1,2\%) investidos na educação superior (valores correntes).

No que diz respeito ao primeiro quinquênio de vigência do PNE 2001-2010, a queda no percentual de investimentos públicos registradas entre os anos de 2001 e 2006 (0,9\% para $0,8 \%$ ) provocou uma perda substancial de recursos financeiros destinados à educação superior. Nesse período, o Produto Interno Bruto (PIB) obteve um crescimento de aproximadamente $100 \%$, saltando de $\mathrm{R} \$ 1,1$ trilhão para $\mathrm{R} \$ 2,3$ trilhões (valores correntes/IBGE), em cinco anos. Em função do alto índice de crescimento do PIB nacional, os investimentos nesse nível de ensino passaram de $\mathrm{R} \$ 9,4$ bilhões $(0,9 \%)$, em 2001, para $\mathrm{R} \$$ 18,9 bilhões $(0,8 \%)$, em 2006, o que representa uma elevação de $100 \%$ (valores nominais). Entretanto, se mantivesse o percentual de investimentos de 2001 (0,9\% do PIB), a evolução seria de $125 \%$, ao passo que os recursos totais - despendidos pelo Governo Federal, Estados, Distrito Federal e Municípios - atingiriam o valor de R \$21,3 bilhões. Nessa perspectiva, a queda de $0,1 \%$ em relação ao PIB, representado no Gráfico 2, traduz um corte de aproximadamente $\mathrm{R} \$ 2,3$ bilhões ( $\mathrm{R} \$ 21,3$ - $\mathrm{R} \$ 18,9)$ somente no ano de 2006, o que equivale a um prejuízo de $13 \%$ em relação ao total de recursos públicos investidos na educação superior. Em 2007, período em que o PIB a preço de mercado alcançou R \$2,5 trilhões, o Estado brasileiro deixou de investir aproximadamente $\mathrm{R} \$ 2,3$ bilhões. Na prática, foram destinados à educação superior $\mathrm{R} \$ 20,4$ bilhões $(0,8 \%$ do $\mathrm{PIB})$, ao passo que, se o

\begin{tabular}{l|l|l|l|l|l|l|} 
(C) Rev. Inter. Educ. Sup. & Campinas, SP & v.3 & n.1 & p.90-113 & jan./abr. 2017 & ISSN 2446-9424 \\
\hline
\end{tabular}


governo tivesse investido o equivalente ao ano de 2001 (0,9\%), os investimentos públicos totais chegariam a $\mathrm{R} \$ 23$ bilhões. Isso representa uma perda de $11 \%$. Os prejuízos seriam ainda maiores se multiplicado ao percentual de investimentos de 2002 (1\% do PIB).

Embora não tenha ocorrido uma evolução do percentual do investimento público em relação ao PIB, o número de alunos formados anualmente nas instituições federais cresceu 69,5\%, saltando de 65.571, em 2001, para 111.157, em 2011. O número de concluintes continuou ascendendo na segunda década do século XXI, passando para 128.084 concluintes no ano de 2014, o que equivale a um crescimento de $28 \%$ (28.138) quando comparado a 2010. Em relação ao número de ingresso nas IFES, observa-se uma elevação de 31,8\% (125.701 - 165.685) nos anos de 2001 a 2004, período em que registrou-se uma queda de $0,1 \%$ sobre os investimentos públicos; mas reduz para 148.206, em 2005, o que representa um retrocesso de 10,5\% (165.685 - 148.206) em relação ao ano de 2004 e um crescimento de 18\% (125.701 - 148.206) quando comparado a 2001. Entre 2001 a 2011, o número de ingresso nas IFES obteve um substancioso aumento de 145,4\% (125.701 - 308.504). Em 2014, registrou-se um total de 346.991 ingressantes nas IFES, um incremento de $12 \%$ (38.487) em relação a 2011. Quanto ao número de instituições federais, em treze anos (20012014) registrou-se um aumento percentual de 59,7\%, passando de 67 para 107 instituições. Adiciona-se a isso, a evolução das taxas de escolarização bruta $(15,10 \%$ para $34,2 \%)$ e líquida (8,9\% para 17,7\%), a concessão a concessão de 2.226.226 bolsas ProUni (integral e parcial) em IES privadas entre os anos de 2005 a 2014, a ampliação do número de matrículas em curso de mestrado e doutorado e o aumento no número de programas de pós-graduação e de bolsas em suas diferentes modalidades, por meio da Capes e do CNPq (BRASIL, 2012a, 2012b, 2012c).

Com base nesse estudo, pode-se dizer que a expansão do ensino superior no país efetivou-se, de modo especial, por intermédio da diversificação das fontes de financiamento (autofinanciamento) e da "otimização" da capacidade física e dos recursos humanos das IFES. A evolução de vários indicadores ligados à educação superior brasileira, justamente no período em que se registrou um incremento de apenas $0,1 \%$ em relação ao PIB, se deve, em grande medida, a diminuição do investimento público direto por estudante nas instituições federais. De acordo com a estimativa, ilustrada no Gráfico 3, no período de 2001 a 2006 ocorreu uma queda de $14,5 \%$, passando de $\mathrm{R} \$ 21.089$ para $\mathrm{R} \$ 18.023$ em valores reais; uma redução de $\mathrm{R} \$ 3.066$ por estudante matriculado nas IFES. Concomitantemente, o segundo ano do governo de Lula da Silva (2004) apresentou o pior nível de investimento da década: $\mathrm{R} \$ 16.157$ por estudante, $23,3 \%$ a menos que o valor correspondente a $2001^{7}$. No ano de

\footnotetext{
${ }^{7}$ Esses valores foram calculados a partir do volume total de recursos financeiros gastos pelas instituições na formação do seu corpo discente. O Tribunal de Contas da União calcula o custo médio por estudante nas instituições federais por meio da seguinte metodologia: primeiramente, soma as despesas correntes das universidades; depois, subtrai $65 \%$ das despesas correntes do hospital universitário, reformas, aposentadorias, pensões, sentenças judiciais, despesa com pessoal cedido (docente e técnico-administrativo) e despesa com afastamento País/Exterior (docente e técnico-administrativo). Por fim, divide o volume total de recursos aplicados pela quantidade de alunos matriculados no ano letivo referente ao exercício, em cursos de: a) \begin{tabular}{l|l|l|l|l|l|l} 
(C) Rev. Inter. Educ. Sup. & Campinas, SP & v.3 & n.1 & p.90-113 & jan./abr. 2017 & ISSN 2446-9424
\end{tabular}
} 
2013, registrou-se o maior nível de investimento nesse início de século, chegando a $\mathrm{R} \$$ 22.753 por aluno (Ver Gráfico 4 ).

Em relação ao investimento direto por estudante no nível superior entre os anos de 2001 a 2010, o Gráfico 3 ilustra a evolução dos recursos despendidos em valores nominais e reais $^{8}$. Em termos nominais, houve forte crescimento no investimento público por aluno nos últimos anos. Em nove anos, o gasto público por aluno no ensino superior cresceu 112,5\%, atingindo, em 2010, $\mathrm{R} \$ 20.013$, para uma base de $\mathrm{R} \$ 9.416$, em 2001. Por outro lado, a estimativa do investimento direto em termos reais, deflacionado pelo índice de preços ao consumidor amplo (IPCA), não apresentou grandes avanços. Os R \$ 9.416 gastos em 2001, a preço nominal, equivalem a $\mathrm{R} \$ 21.089$, quando ajustados ao preço real de 2014. Em função da queda ocorrida entre os anos de 2001 a 2006, referente ao último ano do governo FHC e a todo o primeiro mandato presidencial de Lula da Silva, os investimentos públicos por estudante atingiram a base de valores de 2001 somente a partir de 2011, quando atingiu o valor de R\$ 22.389 por aluno. Em treze anos (2001-2014) registrou-se um aumento percentual de $4 \%$, em termos reais.

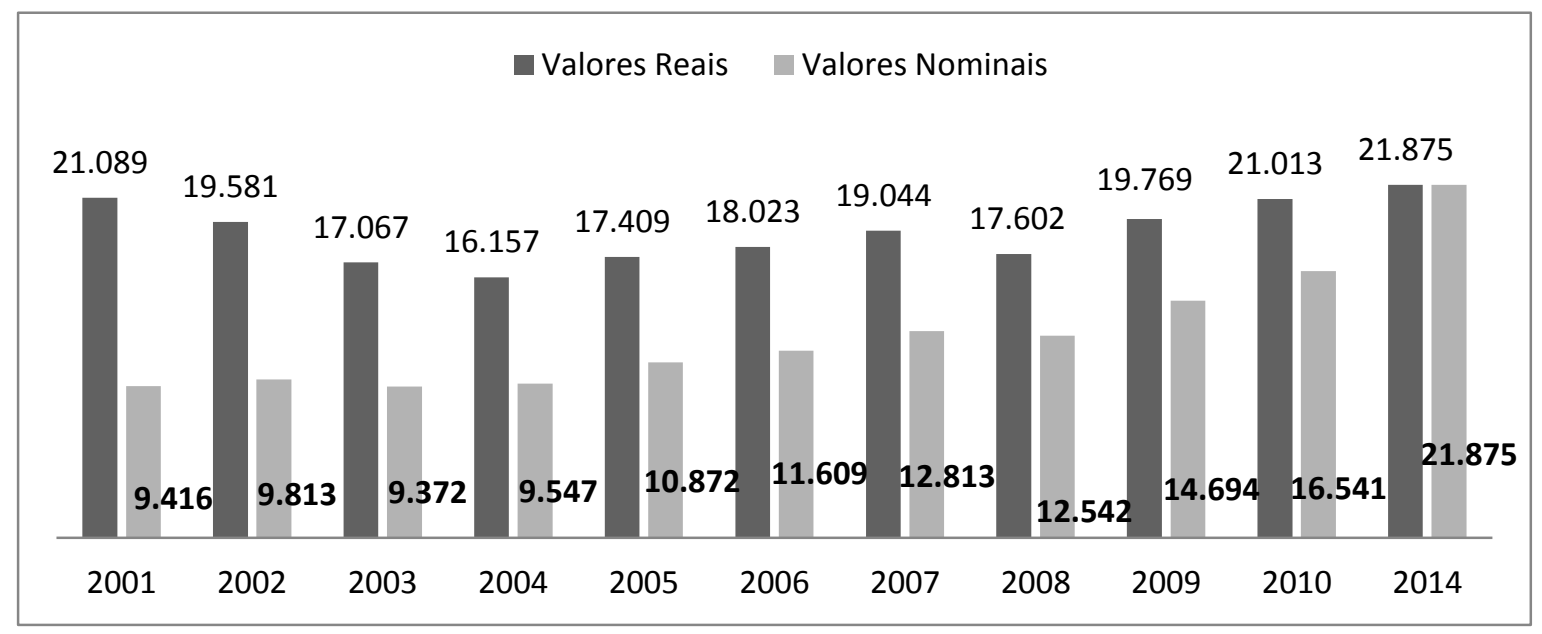

Gráfico 3. Estimativa do investimento público direto na educação superior por estudante em valores nominais e em valores reais, atualizados para 2014 pelo índice nacional de preços ao consumidor amplo (IPCA) - 2001 a 2014

Fonte: INEP/MEC. Elaboração própria.

Notas: I) Utilizaram-se os seguintes grupos de natureza de despesa: pessoal ativo e encargos sociais; outras despesas correntes; investimentos e inversões financeiras; II) Não se incluem nessas informações as seguintes despesas: aposentadorias e reformas, pensões, recursos para bolsas de estudo e financiamento estudantil, despesas com juros e encargos da dívida, amortizações da dívida da área educacional, e a modalidade de aplicação: transferências correntes e de capital ao setor privado. III) A educação superior corresponde aos cursos superiores em tecnologia, demais cursos de graduação (exceto os cursos sequenciais) e cursos de pós-graduação Stricto Sensu - mestrado, mestrado profissional, doutorado (excetuando-se as especializações Lato Sensu). IV)

graduação (noturno e diurno); b) pós-graduação stricto sensu (mestrado e doutorado); c) residência médica (SOARES et. al., 2009) (NETO; VIEIRA, 2006).

${ }^{8}$ Valor nominal (ou a preços correntes) é o valor tal e qual se apresenta. O valor real (ou a preços constantes) é o nominal deflacionado (se houver inflação), ou inflacionado (se houver deflação).

\begin{tabular}{l|l|l|l|l|l|l} 
(C) Rev. Inter. Educ. Sup. & Campinas, SP & v.3 & n.1 & p.90-113 & jan./abr. 2017 & ISSN 2446-9424 \\
\hline
\end{tabular}


Estes dados referem-se aos investimentos em educação consolidados do Governo Federal, dos Estados, do Distrito Federal e dos Municípios.

Apesar dos recursos públicos totais aplicados em educação estarem concentrados principalmente na manutenção e desenvolvimento da educação básica (Gráfico 5), o estudante do ensino superior é o que recebe maior investimento proporcionalmente. Conforme se observa no Gráfico 4, os governos municipais, estaduais e federal gastaram R\$ 5.878 por estudante da educação básica no ano de 2014, enquanto que, no ensino superior, o valor investido por matrícula foi de 3,7 vezes maior: $\mathrm{R} \$ 21.875$. Entretanto, ao analisar a evolução do investimento público direto por estudante na década, nota-se um crescimento de proporções desiguais da educação básica sobre a educação superior: 191,8\% contra 4\%, respectivamente. Em termos reais, os recursos despendidos para a educação básica saltaram de $\mathrm{R}$ \$ 2.014, em 2001, para $\mathrm{R}$ \$ 5.878, em 2014, uma elevação de $\mathrm{R}$ \$ 3.864 por matrícula. Por conta disso, tem-se uma redução da distância entre os investimentos da educação básica e superior. Em 2001, segundo o dados do Ministério da Educação, a diferença era de 10,5 vezes; diminui para 7,7 vezes, em 2005; caiu para 4,5, em 2010; chegando a 3,7 vezes, no último ano do governo de Dilma Rousseff (2011/2014).

No que diz respeito à proporção relativa do investimento público direto em educação, por nível de ensino (Gráfico 3), observa-se um distanciamento gradativo, no período de 2001 a 2011, entre o total de recursos investidos na educação básica e superior. Em 2001, os investimentos em educação básica representavam $80,4 \%$ do total de recursos diretos aplicados em educação, ao passo que a educação superior contava com o equivalente a 19,6\%. No ano de 2009, a proporção de investimento por nível de ensino atingiu 83,8\% contra 16,2\%, respectivamente (Gráfico 4). No ano de 2014, a proporção de investimento público na educação basica e superior se aproxima da extimativa de 2001 , chegando a $80,7 \%$ e 19,3\%, respectivamente. Para tanto, os dados publicados pelo Ministério da Educação (ilustrados nos Gráficos 2, 3, 4 e 5) traduzem, de maneira quantitativa, a prioridade atribuída pelo governo federal ao ensino fundamental e médio em detrimento dos níveis superiores de ensino e pesquisa (graduação, mestrado e doutorado). De modo geral, o estudo sobre as estimativas de investimento público traz à tona informações relevantes acerca do processo de financiamento da educação superior neste início de novo século. 


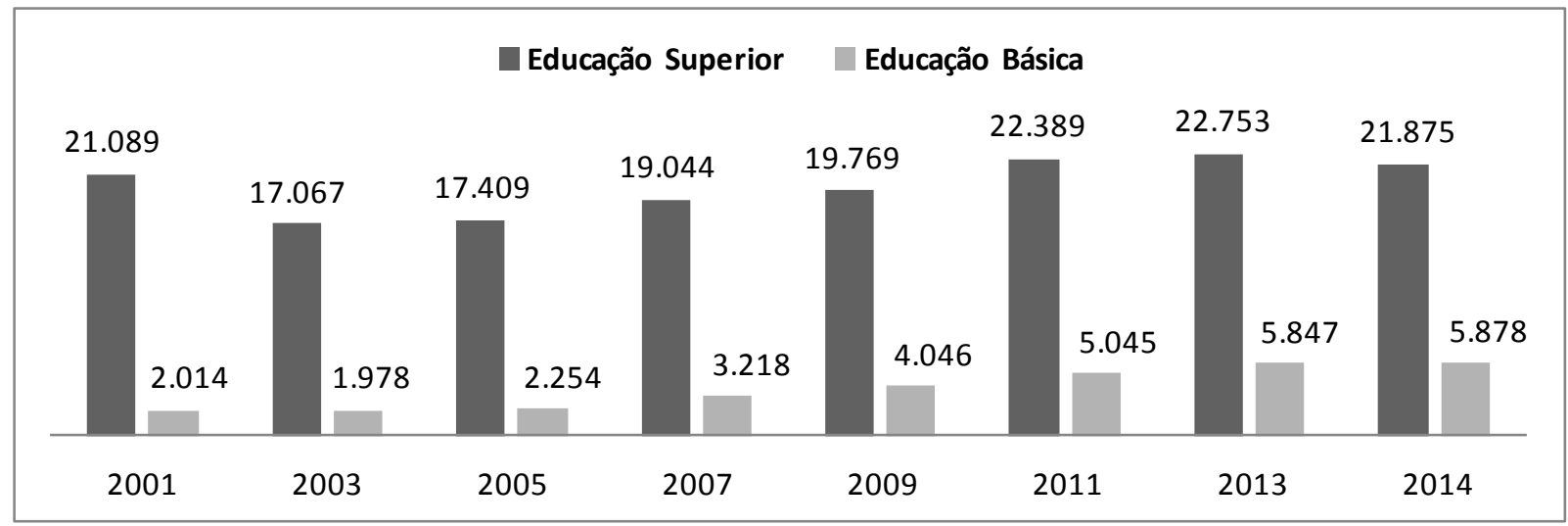

Gráfico 4. Histórico da estimativa do Investimento Público Direto em educação por estudante com valores atualizados para 2014 pelo índice nacional de preços ao consumidor amplo (IPCA) por nível de ensino (educação básica e educação superior) - 2001 a 2014. Fonte: INEP/MEC. Elaboração própria.

Nota: Idem à nota explicativa referente ao Gráfico 3.

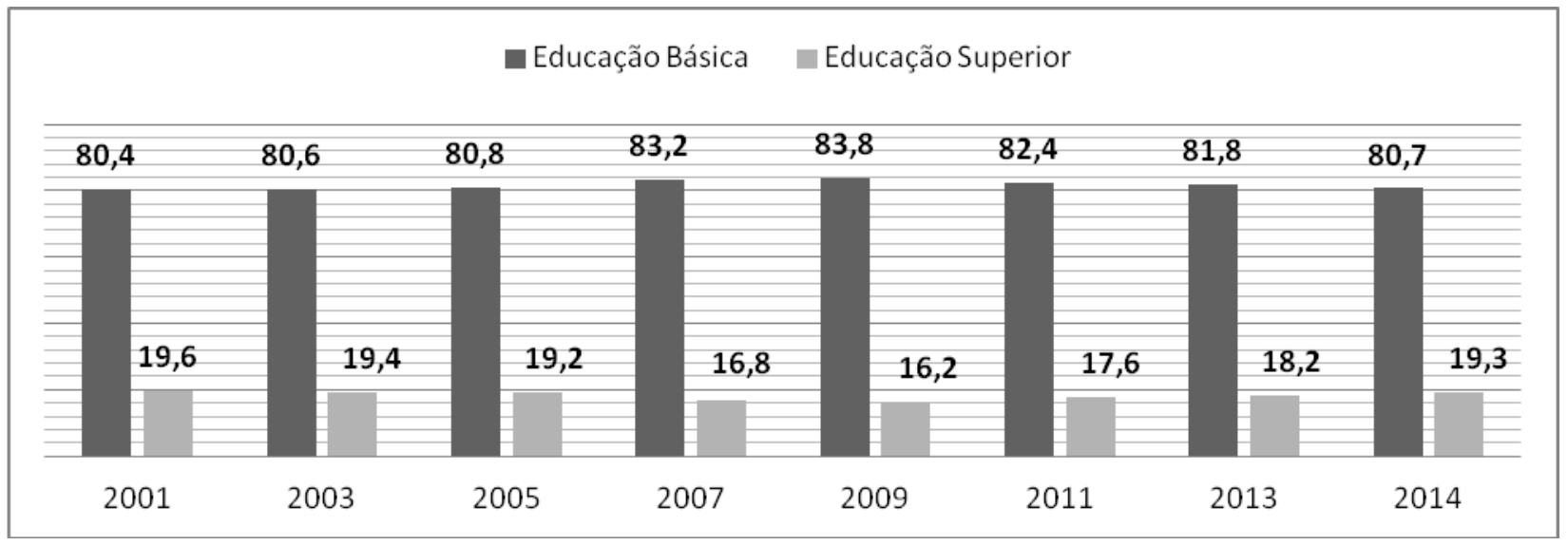

Gráfico 5. Histórico da estimativa da proporção relativa do Investimento Público Direto em educação, por nível de ensino (educação básica e educação superior) - 2001 a 2014.

Fonte: INEP/MEC. Elaboração própria.

Nota: Idem à nota explicativa referente ao Gráfico 3.

Nesse sentido, a leitura das estimativas de investimento público (direto e indireto) na educação superior e das principais fontes de financiamento das IES públicas e privadas permite identificar os avanços, os limites e os desafios do financiamento público no limiar do século XXI. A forma como se estrutura e se organiza o financiamento público revela a tendência à redução do papel do Estado e ao fortalecimento da mercantilização e do empresariamento da educação superior. Esse, por sua vez, comporta dois processos altamente complexos: a expansão do setor privado e a privatização interna das universidades públicas. Visto por esse ângulo, as ações implementadas pelo Ministério da educação, sob a via da

\begin{tabular}{l|l|l|l|l|l|l} 
(C) Rev. Inter. Educ. Sup. & Campinas, SP & v.3 & n.1 & p.90-113 & jan./abr. 2017 & ISSN 2446-9424 \\
\hline
\end{tabular}


parceria público-privada, tem favorecido o setor privado por meio de incentivos governamentais, a exemplo do ProUni, que garante isenção fiscal às instituições de ensino superior em troca de "vagas públicas" à estudantes de baixa renda. A destinação de recursos públicos (diretos e indiretos) para o segmento privado, apregoada em favor do economicismo de cunho neoliberal, cujas diretrizes preconizam a ampliação das oportunidades educacionais a um custo mais baixo para o Estado, oxigenou a expansão de instituições de natureza privada mercantil, por vezes de qualidade duvidosa. Em atribuição a lógica contemporânea de acumulação de capital, a maioria das instituições de ensino superior não desenvolve o ensino associado à pesquisa e extensão, pois objetiva-se, a partir da racionalização das despesas de custeio e pessoal, tornar as mensalidades mais atraentes, aumentar sua participação no mercado e garantir um maior retorno financeiro (LIMA, 2011).

As políticas de financiamento da educação superior brasileira, implementadas em conformidade com as orientações-chave do Banco Mundial, estimularam as IES públicas a diversificar suas fontes de financiamento e a utilizar os recursos financeiros de forma mais eficiente. As universidades públicas tiveram que buscar recursos junto a outras fontes que não a do fundo público, por meio da comercialização de suas pesquisas, da cobrança de mensalidade dos alunos e da prestação de serviços à população. Isso se deve, de modo especial, à garantia de autonomia financeira para geração de receitas próprias (LDB/96), à regulamentação das parcerias público-privadas (PPP) e dos contratos de gestão estabelecidos entre as "universidades federais e as fundações de direito privado, seja pela possibilidade de cobrança de cursos e venda de 'serviços educacionais' pelas IES públicas, seja pela Lei de Inovação Tecnológica, que viabiliza o trabalho docente em empresas privadas e a ação dessas empresas nas IES públicas [...]" (LIMA, 2011, p. 90).

A relação entre o público e o privado na educação superior brasileira tem institucionalizado o controle do mercado sobre a pesquisa científica, a profissionalização da universidade e seu respectivo empresariamento. Em resposta ao economicismo de aporte neoliberal, o Programa de Apoio a Planos de Reestruturação e Expansão das Universidades Federais (Reuni), embora tenha desempenhado um papel preponderante em termos orçamentários, fundamentou-se na racionalização de recursos financeiros pela via da otimização dos recursos humanos e da estrutura física das instituições federais de ensino superior (LIMA, 2011; CHAVES, 2011; GUIMARÃES et. al., 2011). As ações relativas ao processo de reestruturação e expansão do acesso à universidade federal, operada pelo Reuni, resultaram no aligeiramento da formação profissional e na intensificação do trabalho docente. Visto por esse ângulo, as reformas estabelecidas pelo governo federal, na primeira década do novo século, colocaram em risco a autonomia universitária e a provocaram a quebra de indissociabilidade entre ensino, pesquisa e extensão, contrariando os preceitos dispostos no artigo 207 da Constituição Federal de 1988 (LIMA, 2011; SILVA JÚNIOR; SGUISSARDI, 2005). 


\section{PARA FINALIZAR - 0 QUE FAZER DIANTE DESSE QUADRO?}

O financiamento da educação superior certamente é um dos temas mais complexos e controversos a serem enfrentados no cenário das políticas publicas e na projeção do projeto de país que se quer (re)construir. Partindo do princípio de que "a universidade é um bem público", Boaventura de Sousa Santos (2004, p.106-107) questiona "se e em que condições pode um bem público ser produzido por uma entidade privada". Sendo assim, talvez seria irreal pensar o futuro da universidade como bem público, quando há todo um direcionamento focado na mercantilização da educação superior. De qualquer forma, uma das possíveis saídas seria a de fortalecer os espaços democráticos da educação e potencializar a democratização da universidade. O que isso significa? De que forma tais processos podem ser concretizados?

Fortalecer os espaços democráticos da educação implica em ampliar os fóruns de debates sobre a ideia da educação como um bem público, publicizar o processo de empresariamento da educação que está acontecendo no Brasil, sensibilizar e mobilizar a sociedade para que compreenda os riscos que tal processo significa na produção da deterioração da sociedade democrática. Potencializar a democratização da universidade significa promover uma nova instituicionalidade que tem por objetivo aprofundar a democracia interna e externa da própria universidade. Entende-se por democracia externa, no dizer de Santos (2004, p.101) "a passagem do modelo universitário para o modelo plurivesitário", ou seja, fazer com que a própria universidade passe a "assumir a contextualização do conhecimento e a participação dos cidadãos ou comunidades enquanto utilizadores e mesmo co-produtores de conhecimento". Por democracia interna entende-se a permanência de mecanismos que possibilitam a liberdade acadêmica e evitam a proletarização dos docentes e pesquisadores.

A publicização do processo do empresariamento da educação além de fortalecer os espaços democráticos da educação possibilita também a formação de uma consciência crítica sobre os rumos que a educação está sendo conduzida. Nesse sentido os órgãos fiscalizadores passam a ter um papel imprescindível para que os estudiosos, especialistas e a população em geral possam ter acesso às necessárias informações sobre a forma como está sendo conduzidos os recursos do financiamento da educação. Os Tribunais de Contas, o Poder Legislativo, os Ministérios Públicos precisam atuar de forma dinâmica para que os processos de financiamento da educação sejam transparentes, abertos e de livre acesso à população. Mesmo que esses órgãos fiscalizadores sejam constituídos de forma frágil ${ }^{9}$, é imprescindível

\footnotetext{
${ }^{9}$ Em seu artigo "O Financiamento da Educação estatal no Brasil: desafios para sua publicização", Nicholas Davies (2010, p.229-245) analisa a pouca confiabilidade dos órgãos fiscalizadores decorrentes da forma como tais órgãos são constituídos. "Os tribunais de Contas (TCs) são órgãos auxiliares do Poder Legislativo e são dirigidos por conselheiros nomeados segundo critérios políticos, a partir de acordos entre o executivo e os 'representantes' do povo (deputado e vereadores). Isso significa que as contas dos governos tendem a ser avaliadas principalmente ou quase exclusivamente segundo critérios de 'afinidade' entre os TCs e os governos, não necessariamente de acordo com a lei ou normas técnicas, muitas vezes (talvez quase sempre) utilizadas 'seletivamente"'".

\begin{tabular}{l|l|l|l|l|l|l|} 
(C) Rev. Inter. Educ. Sup. & Campinas, SP & v.3 & n.1 & p.90-113 & jan./abr. 2017 & ISSN 2446-9424 \\
\hline
\end{tabular}
}


fortalecer mecanismos de controle, que possam publicizar as informações, os números e a forma como estão sendo distribuídos os recursos.

Uma análise crítica e cuidadosa do financiamento da educação nos leva a concluir com Davies (2010, p.235) que "não basta aumentar os recursos, pois eles podem ser dilapiados pelos governantes e pela máquina estatal, devido a má gestão, superfaturamentos e tantas outras práticas ilícitas". Por isso a importância da publicização, da discussão democrática, da democratização das informações considerados, por enquanto, antídotos para combater a corrupção, a burocratização e tantos outros males que desviam, usam mal e dão uma destinação indesejável aos necessários recursos de financiamento da educação.

\section{REFERÊNCIAS}

AMARAL, Nelson C. Financiamento da educação superior: estado x mercado. São Paulo: Cortez, 2003.

AMARAL, Nelson C. Autonomia e financiamento das IFES: desafios e ações. Avaliação, Campinas; Sorocaba, v. 13, n. 3, p. 647-680, nov. 2008a.

AMARAL, Nelson C. Financiamento da educação superior no Brasil: gastos com as Ifes de Fernando Collor a Luiz Inácio Lula da Silva. In: BITTAR, M.; OLIVEIRA, J. F.; MOROSINI, M. (Org.). Educação superior no Brasil: 10 anos pós-LDB. Brasília: INEP, 2008b. p. 258-282.

AMARAL, Nelson C. O eixo autonomia-avaliação-financiamento em FHC e Lula. In: DOURADO, Luiz F. (Org.). Políticas e Gestão da Educação no Brasil: novos marcos regulatórios. São Paulo: Xamã, 2009. p.169-182.

BANCO MUNDIAL. La ensenãnza superior: las perspectivas de la experiência (el desarrollo em la práctica). Washington/DC: BIRD/Banco Mundial, 1995.

BECHI, Diego. O financiamento da educação superior: uma análise do PNE 2001-2010. 2013. Dissertação (Mestrado em Educação) - Faculdade de Educação, Universidade de Passo Fundo, Passo Fundo, 2013.

BEISIEGEL, Celso R. O Plano Nacional de Educação. Cadernos de Pesquisa, São Paulo, n. 120, p. 207-231, mar. 1999.

BOLLMANN, Maria da G. N. Revendo o Plano Nacional de Educação: proposta da Sociedade Brasileira. Educação \& Sociedade, Campinas, v. 31, n. 112, p. 657 - 676, jul./set. 2010.

BRASIL. Constituição. Constituição da República Federativa do Brasil. Brasília, DF: Senado, 1988.

BRASIL. Lei n. 9.394/96, de 20 de dezembro de 1996. Estabelece as diretrizes e bases da Educação. Diário Oficial da União, Brasília, DF, 23 de dez. 1996.

\begin{tabular}{l|l|l|l|l|l|l|} 
(C) Rev. Inter. Educ. Sup. & Campinas, SP & v.3 & n.1 & p.90-113 & jan./abr. 2017 & ISSN 2446-9424 \\
\hline
\end{tabular}


BRASIL. Ministério da Educação e Cultura. Plano Nacional de Educação: proposta do Executivo ao Congresso Nacional. Brasília, DF: MEC/Inep, 1998.

BRASIL. Lei n. 10.172, de 9 de janeiro de 2001. Institui o Plano Nacional de Educação e dá outras providências. Diário Oficial da União, Brasília, DF, 10 jan. 2001.

BRASIL. Lei n $^{\circ}$ 10.260, de 12 de junho de 2001. Dispõe sobre o Fundo de Financiamento ao estudante do Ensino Superior e dá outras providências. Diário Oficial da União, Brasília, DF, 13 de jul. de 2001.

BRASIL. Lei $n^{\circ} 10.973$, de 2 de dezembro de 2004. Dispõe sobre incentivos à inovação e à pesquisa científica e tecnológica no ambiente produtivo e dá outras providências. Diário Oficial da União, Brasília, DF, 3 de dez. de 2004.

BRASIL. Lei n ${ }^{\circ} 11.096$, de 13 de Janeiro de 2005. Institui o Programa Universidade para Todos - PROUNI, regula a atuação de entidades beneficentes de assistência social no ensino superior; altera a Lei ${ }^{\circ} 10.891$, de 9 de julho de 2004, e dá outras providências. Diário Oficial da União, Brasília, DF, de 14 de jan. 2005.

BRASIL. Lei $\mathrm{n}^{\circ} 11.128$, de 28 de junho de 2005. Dispõe sobre o Programa Universidade Para Todos - PROUNI e altera o inciso 1 do art. $2^{\circ}$ da Lei n ${ }^{\circ} 11.096$, de 13 de jan. 2005. Diário Oficial da União, Brasília, DF, 29 de jun. de 2005.

BRASIL. Ministério da Educação. O Plano de Desenvolvimento da Educação: razões, princípios e programas. Brasília, DF: MEC, 2007a.

BRASIL. Ministério da Educação e Cultura. Decreto n 6.096, de 24 de abril de 2007. Institui o Programa de Apoio a Planos de Reestruturação e Expansão das Universidades Federais REUNI e dá outras providências. Diário Oficial da União, Brasília, DF, 25 de abr. de 2007b.

BRASIL. Ministério da Educação. Instituto Nacional de Pesquisas Educacionais (INEP). Avaliação do Plano Nacional de Educação 2001-2008: políticas, programas e ações do governo federal. Brasília, DF: MEC/INEP, 2009.

BRASIL. Ministério da Educação. Instituto Nacional de Estudos e Pesquisas Educacionais Anísio Teixeira (INEP). Censo da Educação Superior 2010: divulgação dos principais resultados do Censo da Educação Superior 2010. Brasília: INEP, 2011.

BRASIL. Ministério da Educação. Instituto Nacional de Estudos e Pesquisas Educacionais Anísio Teixeira (INEP). Investimentos Públicos em Educação. Disponível em: <http://portal.inep.gov.br/estatisticas-gastoseducacao> Acesso em: 24 ago. 2012a.

BRASIL. Ministério da Educação. Instituto Nacional de Estudos e Pesquisas Educacionais Anísio Teixeira (INEP). Censo da Educação Superior 2010 - Resumo técnico. Brasília: INEP, 2012b. Disponível em: <http://www.abmes.org.br/abmes/public/arquivos/documentos/ resumo tecnico censo educacao superior 2010.pdf>. Acesso em: 10 ago. 2012 b.

BRASIL. Ministério da Educação. Ministério da Educação e Cultura. Programa Universidade para todos (ProUni): dados e estatísticas. Disponível em: $<$ http://prouniportal.mec.gov.br/index.php?option =com_content\&view=category\&id $=26 \&$ Itemid=147>. Acesso em 27 dez. 2012c.

\begin{tabular}{l|l|l|l|l|l|l|} 
(C) Rev. Inter. Educ. Sup. & Campinas, SP & v.3 & n.1 & p.90-113 & jan./abr. 2017 & ISSN 2446-9424
\end{tabular}


BRASIL. Ministério da Fazenda. Secretaria do Tesouro Nacional. Portaria Interministerial $n^{0}$ 163, de 4 de maio de 2001. Dispõe sobre normas gerais de consolidação das Contas Públicas no âmbito da União, Estados, Distrito Federal e Municípios, e dá outras providências. Disponível em: 〈http://www.anvisa.gov.br/legis/portarias/163_01.pdf>. Acesso em: 21 dez. 2012.

CAMARGO, Rubens et al. Sobre o financiamento no Plano de Desenvolvimento da Educação. Cadernos de Pesquisa, São Paulo, v. 38, n. 135, p. 817-839, set./dez. 2008. CARVALHO, Cristina A. Uma análise crítica do financiamento do ProUni: instrumentos de estímulo à iniciativa privada e/ou democratização do acesso à educação superior? In: REUNIÃO ANUAL DA ANPED, 34.: 2011, Caxambu. Anais... Rio de Janeiro: ANPED, 2011. p. 1-20.

CHAVES, Vera L. J. Perfil do financiamento e da expansão do setor público e privado da educação superior brasileira pós-LDB. SIMPÓSIO BRASILEIRO DE POLÍTICA E ADMINISTRAÇÃO DA EDUCAÇÃO, 25.: São Paulo, 2011. Anais... São Paulo: Anpae, 2011, p. 1-11.

CONFERÊNCIA NACIONAL DE EDUCAÇÃO (CONAE). Construindo o Sistema Nacional de Educação: O Plano Nacional Articulado de Educação: diretrizes e estratégias de ação (documento-referência). Brasília : CONAE, 2010.

CORBUCCI, Paulo R.; MARQUES, Paulo M. F. Fontes de financiamento das instituições federais de ensino superior: um estudo sobre a Universidade de Brasília. Brasília: Ipea, 2003. p.1-36.

COSTA QUINTANA, Alexandre; SAURIN, Valter. Fontes de financiamento e despesas por categorias econômicas no ensino superior: uma análise comparativa em três universidades federais da região sul. Revista de Ciências da Administração, v. 7, n. 13, p. 1-20, jan./jul., 2005.

DAVIES, Nicholas. O financiamento público às escolas privadas. 2002. Disponível em: < http://www.uff.br/feuff/departamentos/docs_politica_mural/financiamento_publico_escolas_ privadas.doc>. Acesso em: 28 dez. 2012.

DAVIES, Nicholas. O governo Lula e a educação: a deserção continuada? Educação e Sociedade, Campinas, v.25, n.86, p.245-252, abr. 2004.

DAVIES, Nicholas. O financiamento da educação estatal no Brasil: desafios para sua publicização, Revista Educação Pública, Cuiabá, v.19, n.40, p.229-245, maio/ago., 2010.

DOURADO, Luiz Fernandes. Políticas e Gestão da Educação no Brasil: novos marcos regulatórios. São Paulo: Xamã, 2009.

DOURADO, Luiz Fernandes. Políticas e Gestão da Educação Superior no Brasil: múltiplas regulações. In: . (Org.). Políticas e gestão da educação no Brasil: novos marcos regulatórios. São Paulo: Xamã, 2009. p.149-167 
DOURADO, Luiz Fernandes. Avaliação do Plano Nacional de Educação 2001-2009: questões estruturais e conjunturais de uma política. Educação e Sociedade, Campinas, v. 31, n. 112, p. 677-705, jul./set. 2010.

FARIA, Maria Leonor Veiga; FRANCISCO, Jailton Gonçalves; MELLO, José Manuel Carvalho de. Gestão financeira da pesquisa e pós-graduação em uma universidade federal um estudo de caso. In: SIMPÓSIO DE EXCELÊNCIA EM GESTÃO E TECNOLOGIA, 3.: 2006, Niterói. Mimeo... [S.1.] : [s.n.], 2006.

FREITAS, Claudia M. et.al. Estudos das fontes de recursos e despesas por categoria econômica das universidades federais brasileiras. In: COLOQUIO INTERNACIONAL SOBRE GESTIÓN EM LAS UNIVERSIDADES DE AMERICA DEL SUR, 5.:2005, Mar del Plata. Anais... Mar del Plata: [s.n.], 2005.

FRIGOTTO, Gaudêncio. Fundamentos científicos e técnicos da relação trabalho e educação no Brasil de hoje. In: LIMA, Júlio C.; NEVES, Lúcia M. W. (Org.). Fundamentos da educação escolar contemporânea. Rio de Janeiro: Fiocruz/EPSJV, 2006, p.241-260.

GOERGEN, Pedro. Pós-modernidade, ética e educação. Campinas: Autores Associados, 2005.

GUIMARÃES, André R. et al. A expansão e financiamento da educação superior pública brasileira: perspectivas para o novo PNE (2011 - 2020). Universidade e sociedade, DF, ano XXI, n.48, p. 21-31, jul. 2011.

IANNI, Octávio. A sociedade global. 3 ed. Rio de Janeiro: Civilização Brasileira, 1995.

LIMA, Kátia. Financiamento da educação superior brasileira nos anos de neoliberalismo. In: REUNIÃO DA ANPED NACIONAL, 29. : 2006, Caxambu. Anais... Rio de Janeiro: ANPED, 2006.

LIMA, Kátia R. S. O Banco Mundial e a educação superior brasileira na primeira década do novo século. Ensaio, Florianópolis, v. 14, n. 1, p. 86-94, jan./jun. 2011.

OLIVEIRA, Romualdo Portela de. A transformação da educação em mercadoria no Brasil, Educação e Sociedade, Campinas, v. 30, n.108, p.739-760, out., 2009.

OLIVEIRA, João F. de. Reforma da educação superior: mudanças na gestão e metamorfose das universidades públicas. In: PEREIRA, Filomena M. de A.; MULLER, M. Lúcia R. Educação na interface relação estado/sociedade. Cuiabá: EDUFMT/Capes, 2006, p.11-21.

OLIVEIRA, João Ferreira. A nova reforma da educação superior no Brasil: o processo de desorganização do sistema e de desajustamento da universidade pública. In: SILVA, Rinalva C. (Org.). Educação para o século XX: dilemas e perspectivas. Piracicaba: UNIMEP, 1999, p. $147-159$.

RODRIGUES, José. Os empresários e a educação superior. Campinas: Autores Associados, 2007. 
SANFELICE, J. L. Pós-modernidade, globalização e educação. In: LOMBARDI, J. C. (Org.). Globalização, pós-modernidade e educação. Campinas: Autores Associados/HISTERDBR, 2003, p.3-12.

SANTOS, Boaventura de Sousa. A universidade no século XXI: para uma reforma democrática e emancipatória da Universidade. São Paulo: Cortez, 2004.

SAVIANI, Dermeval. O Plano de Desenvolvimento da Educação: análise do projeto do MEC. Educação e Sociedade, Campinas, v. 28, n. 100 - Especial, p. 1231-1255, out. 2007.

SEVERINO, Antônio Joaquim. O ensino superior brasileiro: novas configurações e velhos desafios. Educar, Curitiba, n.31, p.73-89, 2008.

SILVA, Andréia F.; ALVES, Miriam F. Análise do PNE e PDE: continuidades e rupturas? In: DOURADO, Luiz F. (Org.). Políticas e gestão da educação no Brasil: novos marcos regulatórios. São Paulo: Xamã, 2009. p. $101-118$.

SILVA JÚNIOR, João dos R.; SGUISSARDI, Valdemar. A nova lei da educação superior: fortalecimento do setor público e regulação do privado/mercantil ou continuidade da privatização e mercantilização do público? Revista Brasileira de Educação, n. 29, p. 5-28, maio/ago. 2005.

SOARES, Thiago C. et al. Reuni e as fontes de financiamento das universidades federais brasileiras. COLÓQUIO INTERNACIONAL SOBRE GESTÃO UNIVERSITÁRIA NA AMÉRICA DO SUL, 9. : 2009, Florianópolis. Anais... Florianópolis: [s.n.], 2009. p1-14.

SRF. Demonstrativo de gastos governamentais indiretos de natureza tributária. 2009.

Disponível em: <http://www.receita.fazenda.gov.br/publico/estudotributario/BensTributarios /2010/DGT\%202010.pdf>. Acesso em: 01 jun. 2013.

SRF. Demonstrativo de Gastos Governamentais Indiretos de Natureza Tributária. 2010. Disponível em: http://www.receita.fazenda.gov.br/publico/EstudoTributario/Bens Tributarios 12011/DGT2011.pdf>. Acesso em: 01 jun.2013.

SRF. Demonstrativo de Gastos Governamentais Indiretos de Natureza Tributária. 2011. Disponível em: http://www.receita.fazenda.gov.br/publico/estudotributario/Bens Tributarios /2012/DGT2012.pdf>. Acesso em: 01 jun.2013.

SRF. Demonstrativo de Gastos Governamentais Indiretos de Natureza Tributária. 2012. Disponível em: http://www.receita.fazenda.gov.br/publico/estudotributario/Bens Tributarios 12013/DGT2013.pdf >. Acesso em: 01 jun.2013.

TRIBUNAL DE CONTAS DA UNIÃO (TCU). Relatório de auditoria operacional: Programa Universidade para Todos (ProUni) e Fundo de Financiamento ao Estudante do Ensino Superior (Fies)/ Relator Ministro José Jorge. Brasília: TCU, 2009. Disponível em: <http://portal2.tcu.gov.br/portal/page/portal/TCU/comunidades/programas_governo/areas_atuacao/ed ucacao/Relat\%C3\%B3rio\%20de\%20auditoria Prouni.pdf>. Acesso em: 25 dez. 2012.

UNESCO. Declaração mundial sobre educação superior no século XXI: visão e ação. Paris: UNESCO, 1998.

VALENTE, Ivan. Plano Nacional de Educação. Rio de Janeiro: DP\&A, 2001a.

\begin{tabular}{l|l|l|l|l|l|l} 
(C) Rev. Inter. Educ. Sup. & Campinas, SP & v.3 & n.1 & p.90-113 & jan./abr. 2017 & ISSN 2446-9424
\end{tabular}


VALENTE, Ivan; ROMANO, R. PNE: Plano Nacional de Educação ou carta de intenção? Educação e Sociedade, Campinas, v. 23, n. 80, p. 97-108, set. 2002.

VASCONCELOS, Giovânia M.; BARBOSA, Jenny D. A sustentabilidade financeira da UFS: entraves e alternativas. In: COLÓQUIO INTERNACIONAL SOBRE GESTÃO UNIVERSITÁRIA NA AMÉRICA DO SUL, 9. : 2009, Florianópolis. Anais... Florianópolis: [s.n.], 2009. p. 1-14. 